\title{
Steel as a sustainable choice towards the green building concept
}

\author{
S. H. Taha ${ }^{1}$, M. G. Ibrahim ${ }^{1} \&$ Ahmed AbdelMonteleb M. Ali ${ }^{2}$ \\ ${ }^{1}$ The Department of Environmental Engineering, \\ Egypt-Japan University of Science and Technology (E-JUST), Egypt \\ ${ }^{2}$ Architectural Engineering Department, Faculty of Engineering, \\ Assiut University, Egypt
}

\begin{abstract}
Due to the significant global environmental impacts of building construction through water consumption, energy use, gas emission and solid waste, a building's sustainability becomes the fourth consideration after cost, time and quality for the success of its design and construction. The green building standards state that a building is considered environmentally green whenever its structure and expected use simultaneously match the prescribed environmental standards over the span of its life-cycle. Therefore, the life cycle assessment of different buildings was studied to investigate building sustainability and how to achieve the criteria for green buildings. It was shown that a green building does not have a particular construction method, but it is a set of techniques, materials, and technologies suitably integrated together to improve the environmental performance of the building. Thus, this research will focus on steel as the main construction material which can be an appropriate choice that represents interesting solutions to fulfill the green building standards. The characteristics of durability, adaptability and recyclability of steel structures can definitely be highlighted at construction sustainability principles. Otherwise, the Egyptian steel industry has been performing a great effort to accomplish the optimum environmental performance, provide a high structural performance and quality, and satisfy clients' requirements for sustainability. Data from a private steel plant in Egypt has been compiled as a step to complete the Egyptian life cycle inventory so that the steel industry could be environmentally assessed.
\end{abstract}

Keywords: sustainable construction, green building, steel structures, life cycle inventory. 


\section{Introduction of green building standards}

Although building construction has an economic and social contribution, its environmental impact begins from raw resource extraction, mining, manufacturing, processing, construction, use, and demolition, since an enormous amount of energy is consumed, and a considerable amount of emissions is released in each phase. It is the biggest contributor to Green House Gas (GHG) emissions; which accounted for up to $40-50 \%$. Moreover, it is responsible for $40 \%$ of energy consumption, $30 \%$ of resources consumption, $30 \%$ of waste generation and $20 \%$ of water consumption [1]. Due to increasing awareness of environmental concerns and pressures from various organizations, the construction industry is expected to improve sustainable practices. Some studies have been conducted to find ways to improve current practices and implement green building designs.

A green building is considered a sustainable construction when both the structure itself and its use match the environmental standards through its life-cycle [2-4]. Green building design aims to balance between buildings and the environment. Natural materials are preferable for green buildings as well as using renewable or low energy. Green building does not have a certain construction method, but it is a set of techniques, materials, and technologies suitably integrated together to improve its environmental performance [5].

\subsection{Green Building Rating Systems (GBRS)}

GBRS usually concentrate on materials, energy and water consumption, indoor environmental quality, site, location, operating and management, considering all phases from the design till the end of life cycle [2-5]. GBRS could be either a unique attribute such as an energy star rating system or multi-attribute as LEED, Green Globes and (LBC) within the U.S. and other international programs as; BEAM based in Hong Kong, (BREEAM) in the United Kingdom, CASBEE in Japan.

Many GBRS have recently used life cycle assessment (LCA), a technique which evaluates the environmental impacts through the entire life cycle, to move from a prescriptive approach toward scientific evaluation. For example, LCA has been integrated as a preliminary credit in LEED since 2009 for building assemblies and materials [6].

\subsection{Different studies on LCA of different building materials}

A comprehensive analysis was conducted for various studies [5, 7-15] that focuses on evaluating the environmental impacts of the different materials through the building's life cycle using LCA [16]. Two major issues were found.

Firstly, among different building materials, steel is superior at energy consumption and environmental emissions except for the energy consumption in the use phase which can be reduced by improving its heat preservation.

Secondly, life cycle inventory (LCI) is region-related because the different building considerations differ from one location to another, so providing a transparent, consistent, reachable, and reliable national LCI database for Egypt has 
various benefits for industry and other institutional users [17]. Nowadays, the Egyptian National LCI (ENLCI) has started to be developed [17-19] for the Egyptian cement and brick industries but it has not been finished yet, which delayed conducting a complete LCA for a case study in Egypt. Consequently, this paper reviews and analyzes the steel attributes towards sustainability and performs a database for the Egyptian steel industry.

\section{Materials and methods}

\subsection{Steel attributes towards sustainability}

Andrade et al. [20] have used building sustainability assessment systems in which specific standards are developed to evaluate steel buildings considering different impact categories. Such systems can identify to some extent the benefits of steel construction solutions. SBTool recognized the excellent performance of steel buildings achieved in features like 'energy efficiency' and 'health and comfort'. On the other hand, LEED was more valued regarding steel recycling and reusability whereas BREEAM and DGNB showed a great coverage of the steel benefits $[10,11]$.

It can be concluded that steel construction is an ideal solution to meet sustainability goals based on its attributes and solutions at each phase of a building's life cycle (shown in figure 1) from manufacturing phase till the end of life as follows.

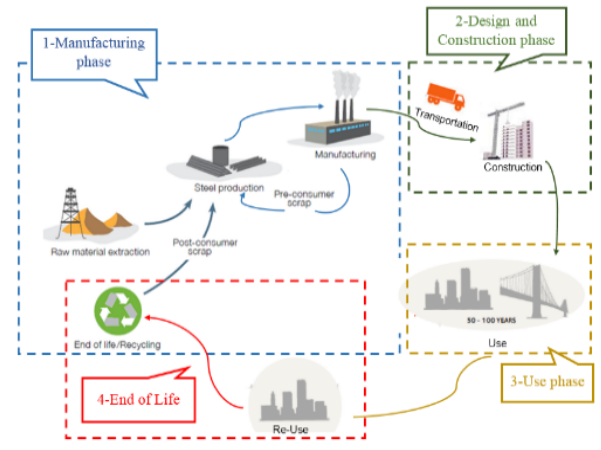

Figure 1: Steel construction at each phase of a building's life.

\subsection{Manufacturing phase}

Three main products can be identified in the manufacturing phase: iron, steel and end products. Manufacturing can be divided into three main steps: producing molten steel, casting and rolling and getting final steel products.

\subsubsection{Production of molten steel}

Most of the emissions generated by the steel industry usually come from general iron reduction, the chemical interaction between carbon and iron ore in blast furnaces to produce molten iron. Therefore, considerable extra reductions in $\mathrm{CO}_{2}$ 
emissions are not feasible if only conventional technologies are used. Innovative technologies have been generated to mitigate the emissions and enhance the efficiency of resource utilization towards more sustainable steel. Other procedures have been proposed including; increasing scraps [22], using carbon-free energy, producing high-performance steel to extend the service life and the reuse and restore $\mathrm{CO}_{2}[20]$.

2.2.1.1 Recycled steel Steel (as shown in Table 1), can be produced at integrated facilities that include blast furnaces, and basic oxygen furnaces (BOF), or open hearth furnaces from iron ore. Another method is performed at a secondary facility using electric arc furnaces (EAFs) which depend on recycled scrap. One of the key attributes of steel is that it is infinitely recyclable without losing its properties in strength, ductility or formability which marks steel recycling as a 'closed-loop'. However, the most challenging issue in the scrap recycling operation is the remaining elements [22]. The effort to separate or remove a particular residual element [23] sometimes becomes too expensive and thereby, primary production becomes a preferred option over recycling.

2.2.1.2 Electric Arc Furnaces (EAF) A significant reduction of $\mathrm{CO}_{2}$ emissions can be reached using EAF. Primary steel produced in an integrated steel mill (IM), emits $2.1 \mathrm{t}$ of $\mathrm{CO}_{2}$ per ton of crude steel (TCS) while only $0.6 \mathrm{t} / \mathrm{TCS}$ of the steel is produced at EAF [22]. Yellishetty et al. [23] has shown that using EAF to generate steel from scraps reduces about $32.14 \%$ up to $40.32 \%$ of the $\mathrm{CO}_{2}$ emissions per ton than using BOF. EAF is also far less energy intensive, one ton of steel through the EAF route consumes 9-12.5 GJ/TCS whereas the BOF steel consumes 28-31 GJ/TCS. Primary steel uses 2.5 times more energy than from melting scrap.

2.2.1.3 Iron ore reduction The current quantity of the available scraps is not enough to meet the steel demand on the market. A possible solution to increase the share of EAF charge is using hydrogen for iron ore reduction. T. In and I. Co. [24] compares current technologies for producing steel from directly reduced iron (solid sponge iron (DRI) or hot briquette iron (HBI)), pig iron, and scrap steel considering $\mathrm{CO}_{2}$ emissions per ton of liquid steel (TLS) (as shown in Figure 2). It has been clearly depicted that $\mathrm{CO}_{2}$ emission in the steel production based on hydrogen reduction iron ore is decreased, but not completely removed.

2.2.1.4 Ultra-Low Carbon dioxide Steelmaking (ULCOS) $\mathrm{CO}_{2}$ levels can be reduced either through innovative steelmaking technologies or the so-called breakthrough technologies. One of these breakthrough projects concerns the redesign of blast furnaces to capture $\mathrm{CO}_{2}$ and storing it. The top gas of the blast furnace is separated and the suitable components recycled back as a reducing agent. Meanwhile, instead of preheated air, oxygen is injected to assist Carbon Capture and Storage (CCS) [26], which has many burdens such as the high cost to apply it in those industries. Another project is the ULCOS program that aims to reduce $\mathrm{CO}_{2}$ emissions by $50 \%$ at least. Globally, other technologies targeting to reduce carbon emissions are currently under research like COURSE-50 (Japan), POSCO (South Korea), China Steel Corporation with Taiwan CCS Alliance 
coordination (Taiwan), blue scope steel and one steel with CSIRO coordination (Australia), and Emirates Steel in the UAE [27].

Table 1: $\quad$ Production of the molten steel process.
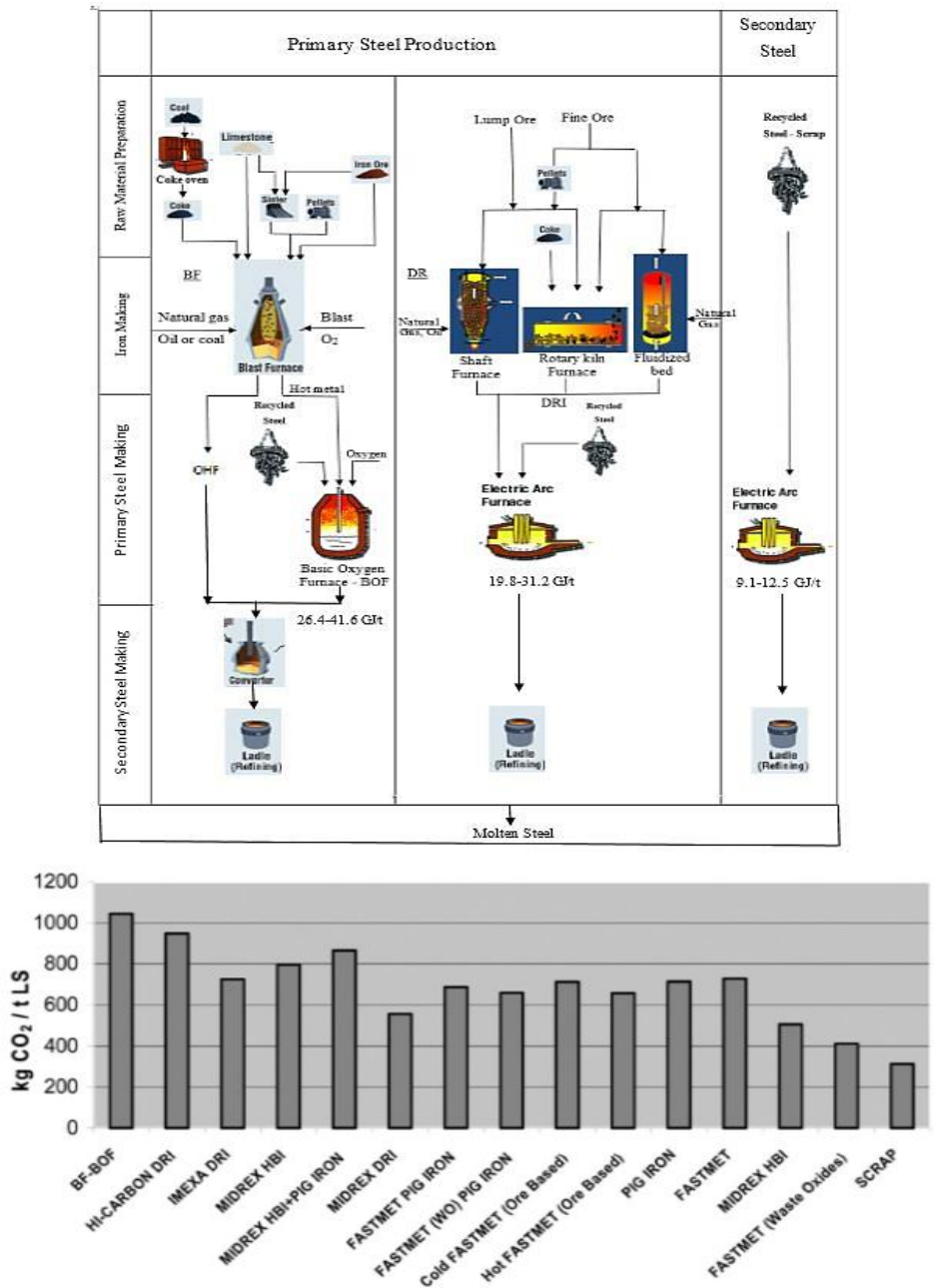

Figure 2: $\quad \mathrm{CO}_{2}$ emissions with current steelmaking technologies [24].

2.2.1.5 By-product reusing Sometimes using the primary route is available more than secondary steel. Meanwhile, the biggest problem is the significant energy amounts consumed through the primary production process: cooking oven gas, blast furnace gas, slag, and BOF-gas. These by-products could be reused to reduce their environmental impacts. For example, the slag could be used as a cement substitute consequently the emissions in the cement production are reduced [25]. 
2.2.1.6 Water recycling Weisenberger [5] referred to the low consumption of fresh water during the steel making process. It is possible to recycle up to $95 \%$ of the water which may lead to net consumption of $0.29 \mathrm{~m}^{3}$ per steel ton. The rate of water use varies from 1 to over $148 \mathrm{~m}^{3} / \mathrm{t}$, according to the World Steel Association Water Management Report. The average consumption of water for BOF route is $28.6 \mathrm{~m}^{3}$ per steel ton while for EAF is $28.1 \mathrm{~m}^{3} / \mathrm{t}$.

2.2.1.7 Steel casting and rolling After the molten steel is released it has to be formed into its semi-final shape. Continuous casting saves time by reducing the required steps. Then the shaping is semi-finalized with hot or cold forming. Through hot forming; heated steel is passed between two rollers to reach the designed thickness to produce slabs, strips, bars or plates. Cold forming is used for wires, tubes, sheets and strips. It is more time consuming, but its products have better mechanical properties, machinability, and can more easily be operated into appropriate sizes and thinner scales.

2.2.1.8 Technologies of steel forming It is not easy to assess the environmental impacts of steel forming technologies. There are some aspects prepared by Ingarao et al. [28], which have to be considered to reach a more environmentally innovative process in energy consumption, Material wasting, GHG emissions, required forming steps in a manufacturing cycle, lubricating conditions, temperature effects and tooling systems. For instance, the conventional mill has some limitations like large width deviation and limited width reduction. The final plate size depends on the first slab. There has been a recent trend of adding a sizing press in front of the mill (as shown in Figure 3), which increases the capability of width reduction. It is a most important step towards weight reduction that improves the slab-rolling productivity and increases production yield.

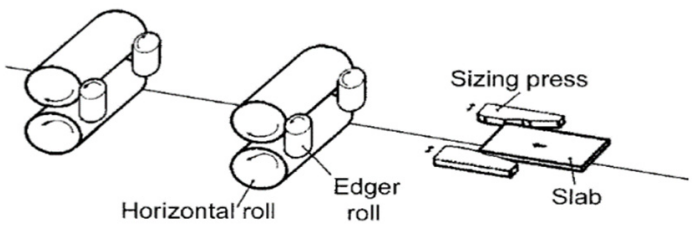

Figure 3: Roughing mill layout with a sizing press [44].

\subsubsection{Steel products}

As previously mentioned, the steel industry is categorized into three levels; crude steel, semi-finished steel, and finished steel. The semi-finished steel comprises slab, billet, bloom, beam, and blank. The slab is used to produce flat products; hotrolled, cold-rolled, and galvanized steel. Tongpool et al. [29] assessed the environmental impacts of the different flat products in Thailand. The slab showed the lowest impacts while the highest were due to the hot-dipped galvanized steel in all impact categories of fossil fuels, global warming, eco-toxicity, minerals, carcinogens, and respiratory inorganics. The impacts of hot-dipped galvanized steel are higher than the electro-galvanized one as a result of the zinc input. A 
slight quantity of zinc can cause high impacts, mostly in the categories of ecotoxicity and minerals.

\subsubsection{Steel manufacturing development}

During the steel production stages, it is known that the mechanical properties over a cross section can be improved by one of these parameters: chemical composition, reduction ratio, and heat treatment. However, all these improvements must be performed in parallel with decreasing $\mathrm{CO}_{2}$ emission, energy consumption, or any other impact categories. A proper comparison of alternatives could be conducted using engineering computer models so the decision could be more accurate. For example, the Steel Environmental Assessment Program (STEAP) [25]. It covers the period from 1965 till 2040. Its processes represent the current practice and the improvements that have previously been discussed.

\subsection{Design phase}

Ingarao et al. [28] compared the sustainable design to the conventional design process. Sustainable design is an integrated process starting from the conceptual stage through pre-design till the design stage. Two types of indicators should be considered for the design phase; core indicators and additional indicators that point to environmental, social and economic building. Steel construction achieves the most requirements of these indicators. Also, the choice of steel structures supports the design of both single and multi-story buildings [30] using different steel elements; columns, girders, connections, or shear walls [31]. Steel structures also enable adding extensions either vertically or horizontally. The social performance category of accessibility due to the longer spans that eliminate intermediate columns creating open floor areas ideal for various needs [30]. They can achieve both building functional demands and uniqueness of their client' needs [17, 19].

\subsection{Construction phase}

The main sustainable issues of steel structures either hot-rolled or cold-formed systems during construction are reducing waste and site impacts including; noise, dust, pollution and traffic congestion by maximizing offsite prefabrication [20].

Aye et al. [33] concluded that using a prefabricated steel system can reduce up to $50.7 \%$ by weight in raw material consumption and $50 \%$ of the embodied energy comparing with the concrete buildings. Several authors [2, 10, 17, 21-23] have discussed off-site construction benefits which are not only minimizing site activity but also are providing efficient, safe, high quality and fast construction [36], in addition to economical handling and transportations [37].

\subsection{Use phase}

Steel buildings are very flexible and adaptable. Their net floor area could be easily changed and optimized without great interventions due to the real free interior spaces. Lightweight buildings can overcome the shortcomings of high thermal inertia that directly affects energy efficiency. When glazed openings, exposure, and shading are well-designed; the solar gains and heat losses are controlled. In 
other words, the compatibility of steel frames with high glazing areas enables more comfortable spaces and takes the daylight income that minimizes energy consumption in artificial lighting [20]. Santos [32] analysed and discussed different approaches to predict energy demands during the use phase of steel buildings.

\subsection{End-of-life phase}

The flexibility of steel structures boosts the reusing of buildings; thus extending their lifespan [20]. Steel buildings can also be easily deconstructed or disassembled at the end of life.

\subsubsection{Reuse phase}

Reuse has distinct advantages over recycling. It preserves the value of energy that is added during manufacturing. Steel building could be extended to construct additional usable space by vertical roof-top extensions, generally using lightweight construction, horizontal extension, or a combination of these extensions as in the Empress State Building [13]. That is not all; steel structures could be strengthened and repaired using fiber reinforced polymers (FRP). A comprehensive research work [39-42] was conducted on retrofitting steel elements including the strengthening of axial and flexural steel members, thinwalled sections and steel composite members.

\subsubsection{End of life}

Steel structure components are certified to reuse in other buildings. Aye et al. [33] determined that reusing the prefabricated units and other elements of the main structure in another new building saved up to $81.3 \%$ of the initial embodied energy and resulted in a great reduction either in the virgin materials or the waste sent to landfill. Regarding the World Steel Association [27], 1 ton of recycled steel saves more than $1.4 \mathrm{t}$ of iron ore, $1.4 \mathrm{t}$ of $\mathrm{CO}_{2}$ emissions, 120 of limestone, $740 \mathrm{~kg}$ of coal and $67 \%$ of energy amounts spent in the steel production process [20].

\section{Theory/calculation}

The first step for spreading the trend of constructing steel structures towards a green building in Egypt is the assessment of the Egyptian steel industry. To continue the ENLCI database, in which is initiated and developed by Ali et al. [17-19] for the Egyptian cement and brick industries, the ENLCI should be continued for the Egyptian steel industry from several Egyptian steel plants. The designed capacity of these plants is determined (as listed in Table 2). As a start, data from a private steel company was collected. In its Direct Reduction Plant (DRP), the oxide pellets were delivered to the Port of Alexandria from Brazil and Sweden then it was transported on conveyors $20 \mathrm{~m}$ in length to the storage silo. There are three gas-based units using the MIDREX process. The reactor type is a shaft furnace under pressure 0.3 Bar at temperature $700-750^{\circ} \mathrm{C}$ using $\mathrm{CO}+\mathrm{H}_{2}$ as a gas reductant. The output from shaft furnace was sent to EAF. For most of the Egyptian industries, not all the input to the steel making is pure iron as scrap can 
exchange it. In the case study plant, the ratio between the used direct reduced irons to the used scrap was almost $30 \%$ DRI to $65 \%$ scrap. The input mix (DRI + scrap + pig iron) is transformed to steel via the reduction of the carbon content and the removal of other impurities. Table 3 highlights the data obtained from the case study.

Table 2: $\quad$ Egyptian installed capacity for main products [43].

\begin{tabular}{llll}
\hline \multicolumn{1}{c}{ Product } & Number of plants & Installed capacity $(\mathrm{t})$ & Sharing $(\%)$ \\
\hline DRI & 1 & $3,000,000$ & 26 \\
Pig iron & 1 & $1,000,000$ & 9 \\
Steel & 8 & $7,265,122$ & 62 \\
Long products & 25 & $8,818,122$ & 75 \\
Flat products & 3 & $2,709,000$ & 23 \\
Sections & 2 & 229,710 & 2 \\
\hline Total & 32 & $11,756,832$ & 100 \\
\hline
\end{tabular}

Table 3: Life cycle inventory of national steel production - Egyptian Steel Plant for 33,000 tons.

\begin{tabular}{|c|c|c|c|c|c|c|c|}
\hline $\begin{array}{c}\text { Inputs and } \\
\text { outputs }\end{array}$ & Unit & $\begin{array}{c}\text { Direct } \\
\text { reduction }\end{array}$ & $\begin{array}{l}\text { Electric arc } \\
\text { furnace }\end{array}$ & $\begin{array}{l}\text { Ladle } \\
\text { furnace }\end{array}$ & $\begin{array}{c}\text { Thin slab } \\
\text { continuous casting }\end{array}$ & $\begin{array}{c}\text { Hot strip } \\
\text { mill }\end{array}$ & Hot rolling \\
\hline \multicolumn{8}{|l|}{ Materials input } \\
\hline Iron ores & ton & $2,266,263$ & & & & & \\
\hline Limestone & ton & & 33,385 & & & & \\
\hline Dolomite & ton & & 107,380 & 10,266 & & & \\
\hline Pig iron & ton & & 216,388 & & & & \\
\hline Iron scrap & ton & & 796,812 & & & & \\
\hline Crude steel & & & & $2,451,163$ & 667,259 & & \\
\hline Cast steel & ton & & & & & 653,600 & $1,768,254$ \\
\hline $\begin{array}{l}\text { Circulating } \\
\text { cooling water }\end{array}$ & $\mathrm{m}^{3}$ & & $96,662,219$ & $11,426,570$ & & $76,513,337$ & $47,511,585$ \\
\hline \multicolumn{8}{|l|}{ Energy inputs } \\
\hline Electricity & MWh & 174,045 & $1,649,148$ & 129,481 & & 102,316 & 128,855 \\
\hline Coke breeze & ton & & 64,198 & 4,591 & & & \\
\hline Natural gas & $\mathrm{Nm}^{3}$ & $418,597,689$ & $5,124,922$ & & $1,307,545$ & $13,673,021$ & $58,622,880$ \\
\hline \multicolumn{8}{|c|}{ Products output } \\
\hline Dri & ton & $1,523,511$ & & & & & \\
\hline Crude steel & ton & & $2,451,163$ & & & & \\
\hline Rolled steel & ton & & & & & 636,185 & $1,684,850$ \\
\hline Dust & & $21.7 \mathrm{mg} / \mathrm{m}^{3}$ & $18.5 \mathrm{~kg} / \mathrm{tms}$ & & & & \\
\hline Lead & & $0.75 \mathrm{mg} / \mathrm{m}^{3}$ & & & & & \\
\hline $\mathrm{Ni}$ & $\mathrm{m}^{3}$ & 1.12 & 0.69 & & & & \\
\hline $\mathrm{Cr}$ & $\mathrm{mg} / \mathrm{m}^{3}$ & 1.12 & 0.11 & & & & \\
\hline Particulate matter & $\mathrm{mg} / \mathrm{m}^{3}$ & 21.7 & & & & & \\
\hline Noise & $\mathrm{dB}$ & 90 & 85.5 & & & & \\
\hline Suspended solids & ppm & 50 & & & & & \\
\hline $\mathrm{CO}$ & $\mathrm{mg} / \mathrm{m}^{3}$ & & 27.36 & & & & \\
\hline NOx & $\mathrm{mg} / \mathrm{m}^{3}$ & & 7.38 & & & & \\
\hline Slag & $\mathrm{kg} / \mathrm{tms}$ & & 170 & & & & \\
\hline Sludge & $\begin{array}{l}\mathrm{kg} / \mathrm{ton} \\
\text { DRI }\end{array}$ & 0.03 & & & & & \\
\hline
\end{tabular}




\section{Conclusion and recommendation}

Steel is not only just a sustainable material but also steel structure buildings, which can significantly provide interesting solutions through the entire life cycle that achieves green building attributes based on their sustainable characterization. Egyptian National LCI (ENLCI) has to be developed to conduct the complete LCA of Egyptian buildings. That is why these papers came to prepare the prolegomena of the Egyptian steel industry. Especially considering that the database of different Egyptian steel plants should be completed so that steel industry in Egypt could be environmentally assessed on the way to applying this trend of steel construction towards green building. Therefore, the environmental assessment of the Egyptian steel industry and the comparisons among different international plants will be held as further research outlook.

\section{Acknowledgements}

The first author would like to thank the Egyptian Ministry of Higher Education (MHE) for providing the financial support (Ph.D. scholarship) for this research, as well as the Egypt-Japan University of Science and Technology (E-JUST) for offering the facility and tools needed to conduct this work.

\section{References}

[1] M. M. Khasreen, P. F. G. Banfill, and G. F. Menzies, Life-Cycle Assessment and the Environmental Impact of Buildings: A Review, no. I, pp. 674-701, 2009.

[2] G. Buildings, Sustainable Development and Green Buildings Održivi razvoj I zelena gradnja, vol. 64, no. 1, pp. 45-53, 2013.

[3] A. Singh and M. Syal, Effects of Green Buildings on Employee Health and Productivity, vol. 100, no. 9, pp. 1665-1668, 2010.

[4] J. G. Allen, P. MacNaughton, J. Guillermo, C. Laurent, S. S. Flanigan, E. S. Eitland, J. D. Spengler, and J. G. Allen, "Green Buildings and Health," pp. 250-258, 2015.

[5] G. Weisenberger, Sustainability and the Structural Engineer, November, pp. 146-150, 2011.

[6] W. B. Trusty, S. Horst, Integrating LCA Tools in Green Building Rating Systems, pp. 1-7.

[7] T. Ngo, A. Mirza, R. Gammampila, L. Aye, and R. Crawford, Life cycle energy of steel and concrete framed commercial buildings, October, pp. 110, 2009.

[8] S. Xing, Z. Xu, and G. Jun, Inventory analysis of LCA on steel- and concrete-construction office buildings, vol. 40, pp. 1188-1193, 2008.

[9] A. A. Guggemos and A. Horvath, Comparison of Environmental Effects of Steel- and Concrete-Framed Buildings, J. Infrastruct. Syst., vol. 11, no. 2, pp. 93-101, 2005. 
[10] T. W. Johnson, Comparison of Environmental Impacts of Steel and Concrete as Building Materials Using the Life Cycle Assessment by, 2006.

[11] Pan \& pro/EPAQ Conference LCA Analysis for steel construction products, 2010.

[12] P. Floors, Comparative case study: steel vs. concrete framing systems.

[13] B. A. Burgan and M. R. Sansom, Sustainable steel construction, vol. 62, pp. 1178-1183, 2006.

[14] J. B. Andrade and S. M. Vieira, Selection of Key Sustainable Indicators to Steel Buildings in Early Design Phases, pp. 167-178.

[15] L. Bragança, S. M. Vieira, and J. B. Andrade, Early Stage Design Decisions: The Way to Achieve Sustainable Buildings at Lower Costs," 2016.

[16] B. Frames, LCA Case Studies LCA of Concrete and Steel Building Frames, pp. 216-224, 1998.

[17] A. AbdelMonteleb M. Ali, A.M. Negm, M. Bady and Mona G. Ibrahim, "Moving towards an Egyptian national life cycle inventory database," Springer: The International Journal of Life Cycle Assessment (Impact: 3.988), doi: 10.1007/s11367-014-0760-z, 19 May 2014

[18] A. AbdelMonteleb M. Ali, Negm, A.M., Bady, M.F., Ibrahim, M.G.E., Suzuki, M., "Environmental impact assessment of the Egyptian cement industry based on a life-cycle assessment approach: a comparative study between Egyptian and Swiss plants", Springer: Clean Technologies and Environmental Policy (Impact: 1. 934), doi:10.1007/s10098-016-1096-0, 01 February 2016.

[19] A. AbdelMonteleb M. Ali, A.M. Negm, "Environmental Impact Assessment of Egyptian Building Materials by using Life Cycle Assessment Methodology", Life Cycle in Practice Conference, 5-6 November 2014, Lille, France.

[20] J. B. Andrade, L. Bragança, and A. Camões, Steel sustainability assessment - Do BSA tools really assess steel properties ?, JCSR, vol. 120, pp. 106116, 2016.

[21] J. B. Andrade, Sustainability Assessment, and Standardisation - Steel Buildings, pp. 213-224, 2010.

[22] Ahmed Ramadan. A.Y. Shash, Effect of Tempcore Processing on Mitigating Problems of Tramp Elements in Low C steel produced from Recycled Material, Journal of Iron and Steel Research, International, 2015, 22(7).

[23] M. Yellishetty, G. M. Mudd, P. G. Ranjith, and A. Tharumarajah, Environmental life-cycle comparisons of steel production and recycling: sustainability issues, problems and prospects, Environ. Sci. Policy, vol. 14, no. 6 , pp. 650-663, 2011.

[24] T. In and I. Co., $\mathrm{CO}_{2}$ Emissions in the steel industry, vol. 48, no. 3, pp. $193-$ 197, 2009.

[25] D. Gielen and Y. Moriguchi, $\mathrm{CO}_{2}$ in the iron and steel industry: an analysis of Japanese emission reduction potentials, vol. 30, pp. 849-863, 2002.

[26] B. O. Furnace, Energy Efficiency and $\mathrm{CO}_{2}$ Reduction in the Iron and Steel Industry, 1970. 
[27] "WorldSteel." www.worldsteel.org

[28] G. Ingarao, R. Di Lorenzo, and F. Micari, Sustainability issues in sheet metal forming processes: an overview, J. Clean. Prod., vol. 19, no. 4, pp. 337-347, 2011.

[29] R. Tongpool, A. Jirajariyavech, C. Yuvaniyama, and T. Mungcharoen, Analysis of steel production in Thailand: Environmental impacts and solutions, Energy, vol. 35, no. 10, pp. 4192-4200, 2010.

[30] SteelConstruction, www.steelconstruction.org

[31] D. Dubina and A. Ciutina, Sustainable detached family house - case study, vol. 3, no. 3, pp. 154-162, 2010.

[32] P. Santos, Influence of Thermal Insulation on the Energy Balance for ColdFormed Buildings, vol. 6, no. 2, pp. 742-766, 2010.

[33] L. Aye, T. Ngo, R. H. Crawford, R. Gammampila, and P. Mendis, Life cycle greenhouse gas emissions and energy analysis of prefabricated reusable building modules," Energy Build., vol. 47, pp. 159-168, 2012.

[34] S. Document, Sustainability of steel-framed buildings, pp. 1-16.

[35] The Sustainable Aspects of Structural Steel, p. 98, 1990.

[36] M. S. Steel, Sustainable steel construction, no. October 2016.

[37] S. Chen and M. Chiu, The 2005 World Sustainable Building Conference, Tokyo, 27-29 September 2005 (SB05Tokyo), Russell J. Bertrand Russell Arch., vol. 2005, no. September, pp. 27-29, 2005.

[38] S. Corporation, Sustainable Steel Structure System for Variable InsideSpace Triple-Skeleton System, vol. 2005, no. September, pp. 27-29, 2005.

[39] A. Al-Mosawe, R. Al-Mahaidi, and X. L. Zhao, Effect of CFRP properties, on the bond characteristics between steel and CFRP laminate under quasistatic loading, Constr. Build. Mater. vol. 98, pp. 489-501, 2015.

[40] N. A. Peiris, Steel Beams Strengthened with Ultra High Modulus, 2011.

[41] S. Rizkalla, M. Dawood, and D. Schnerch, Development of a carbon fiber reinforced polymer system for strengthening steel structures, Compos. vol. 39, no. 2, pp. 388-397, 2008.

[42] J. G. Teng, T. Yu, and D. Fernando, Strengthening of steel structures with fiber-reinforced polymer composites, J. Constr. Steel Res., vol. 78, pp. 131143, 2012.

[43] B. Report, Industrial energy efficiency project, 2014.

[44] M. Chun, I. Ahn, and Y. Moon, Deformation Behavior of a Slab with Width Reduction in a Hot Mill, vol. 14, June, pp. 408-412, 2005. 